\title{
Vascular Plant Composition and Diversity of a Coastal Hill Forest in Perak, Malaysia
}

\author{
S. Ghollasimood (Corresponding author), I. Faridah Hanum, M. Nazre, Abd Kudus Kamziah \& A.G. Awang \\ Noor \\ Faculty of Forestry, Universiti Putra Malaysia \\ 43400, Serdang, Selangor, Malaysia
}

Tel: 98-915-756-2704Ｅ-mail: sghollassi@yahoo.com

Received: September 7, $2010 \quad$ Accepted: September 20, $2010 \quad$ doi:10.5539/jas.v3n3p111

\begin{abstract}
Vascular plant species and diversity of a coastal hill forest in Sungai Pinang Permanent Forest Reserve in Pulau Pangkor at Perak were studied based on the data from five one hectare plots. All vascular plants were enumerated and identified. Importance value index (IVI) was computed to characterize the floristic composition. To capture different aspects of species diversity, we considered five different indices. The mean stem density was 7585 stems per ha. In total 36797 vascular plants representing 348 species belong to 227 genera in 89 families were identified within 5-ha of a coastal hill forest that is comprises $4.2 \%$ species, $10.7 \%$ genera and $34.7 \%$ families of the total taxa found in Peninsular Malaysia. Based on IVI, Agrostistachys longifolia (IVI 1245), Eugeissona tristis (IVI 890), Calophyllum wallichianum (IVI 807), followed by Taenitis blechnoides (IVI 784) were the most dominant species. The most speciose rich families were Rubiaceae having 27 species, followed by Dipterocarpaceae (21 species), Euphorbiaceae (20 species) and Palmae (14 species). According to growth forms, $57 \%$ of all species were trees, $13 \%$ shrubs, $10 \%$ herbs, $9 \%$ lianas, $4 \%$ palms, $3.5 \%$ climbers and $3 \%$ ferns. Diversity indices were higher along the stream side and species accumulation curve showed sampling area captured a high proportion of the species richness.
\end{abstract}

Keywords: Coastal hill forest, Diversity indices, Importance value index, Malaysia

\section{Introduction}

South-east Asian tropical rainforest with its unique and high proportions of endemic plants need greater effort in studying biodiversity. This unique flora result largely from millions years of independence evolution during the Tertiary, when wide oceanic barriers made dispersal between regions (Morely 2003), and have survived the convergence of New Guinea with Southeast Asia (Primack and Corlett 2005). Cataloguing total species richness in any country or region special in tropical and subtropical region is highly demanding (Villasenor et al. 2005) to provide information for managers, environmental planners, nature reserve designers and ecologists (Sang 2009) and a global map of plant diversity will powerfully inform biogeographical and conservation work in many ways. Bidin and Latiff (1995) estimated about 12500 species of the seed plants in the flora of Malaysia and Turner (1997) enumerated 8198 species in Peninsular Malaysia including 632 fern species, 27 Gymnosperms, 5529 Dicotyledons, 2010 Monocotyledons within 248 families and 1651 genera. Based on recent updates, the flora has over 8300 species (Kamarudin and Turner 2004, Latiff and Turner 2002a, 2002b, 2003). Most attempts to explain the variation in floristic composition of hill and lowland forest in Peninsular Malaysia have focused on woody stems ( $\geq 1 \mathrm{~cm}$ ) (Abdul Hayat et al. 2010, Okuda et al. 2003, Condit et al. 1996, Awang Noor and Faridah Hanum 2008) rather than small individuals. Factor causing variation in species richness may differ between life forms of plants. A comparison of various life forms allows a finer resolution of precise casual factors. Thus, in the present study, we analysed the richness of different life forms along elevation gradient (45-350 $\mathrm{m}$ a.s.1.), floristic composition and diversity of vascular plants in a coastal hill forest from Pangkor Island in Perak, Peninsular Malaysia.

\section{Materials and Methods}

\subsection{Study area}

This study was performed in Sungai Pinang Permanent Forest Reserve. Pulau Pangkor (Fig 1) is an island located on the west coast of Peninsular Malaysia between $04^{\circ} 13.0^{\prime} \mathrm{N}$ latitude and $100^{\circ} 33.0^{\prime} \mathrm{E}$ longitude. It is one of the famous and well known islands in Malaysia with area of eight square kilometres and classified as 
coastal hill forest with a high conservation. The climate is typically humid tropical and seasonal heavy rain (Meteorology site, Kuala Lumpur 2010), February and March are the driest months, mean annual rainfall is $1820.23 \mathrm{~mm}(2000-2010)$. The highest mean temperature is in February to May (average $27.65{ }^{\circ} \mathrm{C}$ ) and the minimum occurs during September to December (average $26.8^{\circ} \mathrm{C}$ ) (data courtesy of Meteorology Office, Kuala Lumpur). The elevation of the study area ranges from 54 to $152 \mathrm{~m}$ above the sea level. The texture of topsoil is mainly sandy loam.

\subsection{Methods and data analysis}

Five plots of 1-ha (each $100 \times 100 \mathrm{~m}$ ) were established and subdivided into 100 subplots of $10 \times 10 \mathrm{~m}$ between 45 and $152 \mathrm{~m}$ above sea level. Each subplot was systematically surveyed by enumerating and identifying all vascular plants and measuring trees with height and diameter at breast height $(\mathrm{DBH}) \geq 5 \mathrm{~cm}$. tDuring the sampling, specimens of all plants groups were collected, fixed and brought back to the herbarium of Forestry Faculty, Universiti Putra Malaysia (UPM) and identified on the basis of regional Flora. In addition, local names and medicinal plants were recorded and the final verification was done at the Forestry Research Institute Malaysia (FRIM).The importance value index (IVI) was assigned to describe the species composition of the plots and was calculated as the sum of the following two variables (Curtis and McIntosh 1950): Relative density $=($ number of individuals of a species/total number of individuals $) \times 100$

Relative frequency $=($ frequency of a species/sum frequencies of all species $) \times 100$

ANOVA test was used to determine the differences in richness among plots according growth-forms. Linear regressions of species richness with altitude were also performed using SPSS (version 17.0). A variety of commonly used diversity indices were computed in order to measure alpha diversity for each plot. Species richness is the number of species in the community. Richness indices are based on the relationship between $\mathrm{S}$ and the total number of individuals observed, $\mathrm{N}$, which increases with increasing sample size. Analysis was conducted using EstimateS (Statistical estimation of species richness and shared species from samples) version 8.2.0. (Colwell 2006). The following formulas were used to capture different aspects of species diversity and richness:

Simpson index (Krebs 1999):

$$
\begin{aligned}
& 1-\mathrm{D}=1-\sum_{i=1}^{s}\left\{\frac{\mathrm{n} i(\mathrm{n} i-1)}{\mathrm{N}(\mathrm{N}-1)}\right\} \\
& 1-\mathrm{D}=\text { Simpson's index of diversity } \\
& \mathrm{n}_{i}=\text { Number of individuals of species } i \text { in the sample } \\
& \mathrm{N}=\text { Total number of individuals in the sample } \\
& \mathrm{s}=\text { Number of species in the sample }
\end{aligned}
$$

The Shannon-Wiener index (Krebs 1999):

$$
\begin{aligned}
& \mathrm{H}^{\prime}=\sum_{i=1}^{s}\left(\rho_{\mathrm{i}}\right)\left(\log _{2} \rho_{\mathrm{i}}\right) \\
& \mathrm{s}=\text { Number of species } \\
& \rho_{i}=\text { Proportion of total sample belonging to } i \text { th species }
\end{aligned}
$$

Alpha Fisher's index of diversity (Magurran 2004):

$$
\begin{aligned}
& \mathrm{S}=\boldsymbol{\alpha} \log \left(1+\frac{\mathrm{N}}{\mathrm{a}}\right) \\
& \mathrm{S}=\text { Total number of species in the sample } \\
& \mathrm{N}=\text { Total number of individuals in the sample } \\
& \alpha=\text { Index of diversity }
\end{aligned}
$$


In addition, we tested two more indices, the Chao and Jackknife estimators of species richness that are based on the incidence (presence/absence) of species.

The Chao index (Chao 1984):

$$
\begin{aligned}
& \mathrm{C}=\mathrm{S}+\left(\frac{\mathrm{S} 1^{2}}{2 \mathrm{~S} 2}\right) \\
& \mathrm{C}=\text { Chao index } \\
& \mathrm{S}=\text { Species number } \\
& \mathrm{S}_{1}=\text { the total number of species represented by a single individual } \\
& \mathrm{S}_{2}=\text { the total number of species represented by two individuals }
\end{aligned}
$$

And the jackknife index (Chao 1984):

$$
\begin{aligned}
& \mathrm{J}=\mathrm{S}+\left\{\frac{\mathrm{S} 1(2 \mathrm{~N}-3)}{\mathrm{N}}-\frac{\mathrm{S} 2(\mathrm{~N}-2)^{2}}{\mathrm{~N}(\mathrm{~N}-1)}\right\} \\
& \mathrm{S}=\text { species number } \\
& \mathrm{N}=\text { individual number } \\
& \mathrm{S}_{1}=\text { the total number of species represented by a single individual } \\
& \mathrm{S}_{2}=\text { the total number of species represented by two individuals }
\end{aligned}
$$

\section{Results and Discussion}

\subsection{Floristic composition}

In total 36797 vascular plants representing 348 species belong to 227 genera in 89 families were identified (Appendix 1), two could only be identified to genus, one climber and three herbs were remained unknown within five 1-ha of a coastal hill forest that comprises $4.2 \%$ species, $10.7 \%$ genera and $34.7 \%$ families of the total taxa found in Peninsular Malaysia. Plant density was 7358 individuals per ha. Agrostistachys longifolia (IVI 1245), Eugeissona tristis (IVI 890), Calophyllum wallichianum (IVI 807), followed by Taenitis blechnoides (IVI 784) were dominant species (Table 1,2). The most speciose rich families were Rubiaceae having 27 species, followed by Dipterocarpaceae (21 species), Euphorbiaceae (20 species) and Palmae (14 species), while more than 23 families were singletons (represented by only one species). Euphorbiaceae had the largest number of individuals (5.5\% of plants), followed by Guttiferae (5\%), and Dracaenaceae (4.8\%). Table 3 shows the number of species and individuals according to growth form. Plants were distributed according to growth forms as follows: $57 \%$ of all species were trees, $13 \%$ shrubs, $10 \%$ herbs, $9 \%$ lianas, $4 \%$ palms, $3.5 \%$ climbers and $3 \%$ ferns. Evidently, trees show more equitable distribution of species across plots and most of them are economically important. Tree species like Agrostistachys longifolia, Calophyllum wallichianum, Xanthophyllum affine and Swintonia floribunda were the most populated species.

This island harbours 122 medicinal species (Burkill 1935) in 98 genus and 57 families; Rubiaceae (12 species), Guttiferae (10 species), Dracaenaceae (7 species), Euphorbiaceae (6 Sspecies), Araceae and Zingiberaceae (4 species each) were the most speciose medicinal families (Appendix 1). The dominant climber and liana species were Scindapsus scortechinii representing 35\% of climbers (74\% of individuals) and Dalbergia parviflora representing $26 \%$ of lianas (1.3\% of individuals), respectively. Leguminosae, Connaraceae and Araceae were the most species rich climber families (woody and non-woody). Lianas are dependent on trees for their support, and thus the availability of suitably sized support is a major factor controlling the abundance and distribution of lianas (Putz and Holbrook 1991). The common species in herbaceous layer were Globba variabilis and Etlingera metriocheilos. Eugeissona tristis was a dominant palm, Dracaena pendula a dominant shrub, and Taenitis blechnoides was a dominant fern.

Table 4 also shows the percentage of medicinal and endemic species according to growth -forms. In Malaysia there is over 1000 medicinal species (Latiff et al. 1980) and about 13\% of these species are found in this forest. 
Species composition and number of individuals differed between plots (Figure 2). Distribution of plant species in natural vegetation is usually not stochastic. It occurs in patterns that are present at several spatial and temporal scales. Each species is expected to be most abundant where the environmental conditions are most favorable for it. In this study variation in plant community structure and composition were attributed to the characteristics of physical environment. The number of herbs in the first plot were higher than the other plots, simply the presence of stream was a factor that favoured higher values of diversity (Gazol and Ibanez 2010) and some species located in streamside environments.

Altitude is a factor which is correlated with resources and regulators of plant growth (Kazakis et al. 2007). In this study linear regression of plant richness against altitude was significant (Figure 3). Third plot showed a trend of decreasing richness for most growth forms with increasing altitude and the main reason is altitude. The negative influence of elevation on diversity has been widely reported in studies (Gazol and Ibanez 2010, Odland and Birks 1999, Körner 2002, Pickering et al. 2008, Wang 2006). Overall, elevation showed significant linear regression with herb, liana, fern and tree (Table 5). Although the number of trees reduced with increasing elevation, the number of trees with $\mathrm{dbh} \geq 5 \mathrm{~cm}$ in higher altitude was noteworthy (the details on distribution of trees species will be published soon in a different paper).

Regression of elevation and palm, climber, epiphyte and shrub richness showed no significant relationship (Table 5). Daque et al. (2002), Ruokolainen and Vormisto (2000) and Ruokolainen et al. (2002) indicated that palms are less sensitive to environmental effect and more wide-spread than smaller plants.

Orchidaceae is the most speciose family in the flora of Malay Peninsula with 853 species (Turner 1997). In our study, however, this family was poorly represented (only 5 species) and most of them appeared in the second and third plots in upper canopy crowns to get maximum sea breeze.

\subsection{Species accumulation curve}

Hill and Hamer (2002) believed communities should be sampled adequately (usually assessed with species accumulation curve). Species accumulation curve shows how species richness increases until eventually the curve levels off with increasing sample size and the number of individuals inventoried. The graph suggests that our sampling area captured a high proportion of the species richness; the point at which the curve flattens indicates a minimum viable sample size on which a diversity or richness index should be based (Magurran 1988). Figure 4 shows the curve based on the area sampled stabilized in third plot. Tropical ecologists believe species richness reaches an asymptote at 1-3 ha (Gentry 1988, Tuomisto et al. 1995, McLaren, et al. 2005). Faridah Hanum et al. (2008) in a case study in a logged-over forest in Ayer Hitam Forest found out increasing the size of study area more than five hectare did not have any increment on species richness.

\subsection{Species Diversity}

A variety of diversity measures were computed to describe the heterogeneity of the plots. All diversity indices, including non-parametric estimators, increased with the number of individuals in a sample (Table 6). The majority of the 300 species ( $82 \%$ of total species) inventoried appeared in the first plot, and therefore this plot is characterized by high diversity $(215,146,182,154$ species found in plots 2 to 5 , respectively). The Fisher's alpha is low when the number of species is low. This index is less affected by the abundance rarest or commonest species diversity $(\alpha)$ range from 25.46 to 51.38 and the average for all plots is 35.23 . The Shannon-Winner's index measures the average degree of "uncertainty" in predicting to what species individuals chosen at random will belong (Ludwig and Reynolds 1988). Uncertainty may be visualized as being synonymous with diversity (Krebs 1999), therefore, the higher the degree of uncertainty, the higher the diversity. Diversity index fell within high range (3.54 to 4.98 ) while the average for all plots gave $H^{\prime}=3.99$. Simpson index proposes that diversity is inversely related to the probability that two individuals picked at random from a sample belong to the same species. Simply stated, if the probability is high the diversity is low. Simpson's index varies from 18.09 to 45.43 and the average is 27.62 . According to this index the first plot was more diverse than the others; this could be related to the relatively large number of abundant species. The evenness is considered high when it varies near value of 1 . When all species are abundant, an evenness index would be maximum and decrease towards zero as the relative abundances increase. In this study area the average of Simpson's measure of evenness is low.

\section{Conclusion}

The quantitative inventory of a coastal hill forest helps to complete the description of biodiversity and plant composition. Our results indicate this forest with 55 endemics and 13\% of medicinal species found in Malaysia is unique and offer numerous non-tangible benefits such as invaluable storehouse of genetic resources useful for 
indigenous species. Diversity indices are still widely used in plant ecology to evaluate survey and conserve ecosystems and using richness estimators can improve our evaluation of diversity. Plant diversity is influenced by a multitude of environmental factors, but in this study area streamside was the main factor in determining diversity and majority of herb species were found near the stream.

Monitoring studies such as the current one are of utmost importance and provide insights into the responses of coastal hill forest to climate change and also because this island is a tourist's attraction place, the future inspection need to see the changes according to number of species.

\section{References}

Abdul Hayat, M. S., Kamziah A K, Faridah-Hanum, I., Awang Noor, A. G., Nazre, M. (2010). Assessment of plant diversity at Pasir Tengkorak Forest Reserve, Langkawi Island, Malaysia. Journal of Agricultural Science, Vol 2, No.1.

Awang Noor, A. G., Faridah-Hanum, I. (2008). Relationship between economic value and species diversity of timber resources in a hill forest in Peninsular Malaysia. Journal of sustainable development, Vol. 1, No.2.

Bidin, A. A. and Latiff, A. (1995). The status of terrestrial biodiversity in Malaysia. In: A. H. Zakri,. (Eds.). prospects in biodiversity prospecting. Genetic Society of Malaysia \& Universiti Kebangsaan Malaysia. pp. 59-76.

Burkill, I. H. (1935). A dictionary of the economic products of the Malay Peninsula.s.

Chao, A. (1984). Nonparametric estimation of the number of classes in a population. Scan J Statist, 11, 265-270.

Colwell, R. K. (2006). EstimateS (Statistical estimation of species richness and shared species from samples).

Purl.Oclc.org/estimates.

Condit, R., Hubbell, S. P., Lafrankinkie, J. V., Sukumar, R., Manokaran, N., Foster, R. B., Ashton, P. (1996).

Species-area and species-individual relationships for tropical trees: a comparison of three 50-ha plots. Journal of Ecology, 84, 549-562. doi:10.2307/2261477, http://dx.doi.org/10.2307/2261477

Curtis, J. T. and McIntosh, R. P. (1950). The interrelation of certain analytic and synthetic phytosociological characters. Ecology, 31, 434-455. doi:10.2307/1931497, http://dx.doi.org/10.2307/1931497

Duque, A., Sanchez, M., Cavelier, J. \& Duivenvoorden, J. F. (2002). Different floristic patterns of woody understorey and canopy plants in Colombian Amazonia. Journal of Tropical Ecology, 18, 499-525. doi:10.1017/S0266467402002341, http://dx.doi.org/10.1017/S0266467402002341

Faridah Hanum, I., Philip, L., Awang Noor, A. G. (2008). Sampling species diversity in Malaysian rainforest: the case of a logged-over forest. Pak. J. Bot., 40(4), 1729-1733.

Gazol, A. and Ibanez, R. (2010). Variation of plant diversity in a temperate unmanaged forest in northern Spain. Plant Ecology, 207(1), 1-11. doi:10.1007/s11258-009-9649-5, http://dx.doi.org/10.1007/s11258-009-9649-5

Gentry, A. H. (1988). Changes in plant community diversity and floristic composition on environmental and geographical gradients. Annals of the Missouri Botanical Garden, 75, 1-34. doi:10.2307/2399464, http://dx.doi.org/10.2307/2399464

Hill, J. K. and Hamer, K. C. (2002). Using species abundance models as indicators of habitat disturbance in tropical forests. Journal of Applied Ecology, doi:10.1046/J.1365-2664. doi:10.1046/J.1365-2664, http://dx.doi.org/10.1046/J.1365-2664

Kamarurdin, M. S., Turner, I. M. (2004). Quaterly notes: New taxa andrecords of Malaysian vascular plants. Folia Malaysiana, 5(1), 65-68.

Kazakis, G., Ghosn, D., Vogiatzakis, I. N., Papanastasis, V. P. (2007). Vascular plant diversity and climate change in the alpine zone of the Lefka Ori, Crete. Biodivers Conserv., 16, 1603-1615. doi:10.1007/s10531-006-9021-1, http://dx.doi.org/10.1007/s10531-006-9021-1

Körner, C. (2003). Alpine plant life. Springer, Berlin.

Krebs, C. J. (1999). Ecological methodology. Addison Wesley Longman.

Latiff, A., Ismail, G., Omar, M., Said, M. I., Kadri, A. (1980). A multivariate approach to the study of medicinal plants in Malaysia. Journal Singapore Nationla Academy of Science, 13, 101-113.

Latiff, A. and Turner, I.M. (2002a). Quaterly notes: New taxa and records of Malaysian vascular plants. Folia Malaysiana, 3(1), 67-68. 
Latiff, A. and Turner, I.M. (2002b). Quaterly notes: New taxa and records of Malaysian vascular plants. Folia Malaysiana, 4(2), 129-132.

Latiff, A. and Turner, I.M. (2003). Quaterly notes: New taxa and records of Malaysian vascular plants. Folia Malaysiana, 4(3\&4), 227-230.

Ludwig, J. A. and Reynold, J. F. (1988). Statistical ecology: a primer on methods and computing. New York: John Wiley \& Sons.

Magurran A. E. (1988). Ecological Diversity and Its Measurement. Chapman and Hall, London, pp.179

Magurran, A. (2004). Measuring biological diversity. Blackwell Publishing, Oxford.

McLaren, K. P., McDonald, M. A., Hall, J. B., Healy, J. R. (2005). Predicting species response to disturbance from size class distributions of adults and saplings in a Jamaican tropical dry forest. Plant Ecology, 181, 69-84. doi:10.1007/s11258-005-3497-8, http://dx.doi.org/10.1007/s11258-005-3497-8

Morely, R. J. (2003). Interplate dispersal paths for megathermal angiosperms. Perspectives in Plant Ecology and Evolution, 6, 5-20. doi:10.1078/1433-8319-00039, http://dx.doi.org/10.1078/1433-8319-00039

MOSTE. (1997). Biodiversity assessment in Malaysia. Kuala Lumpur: Ministry of Science, Technology and environment.

Odland, A., Birks H. J. B. (1999). The altitudinal gradient of vascular plant richness in Aurland, Western Norway. Ecography, 22, 548-566.

Okuda, T., Suzuki, M., Adachi, N., Quah, E.S., Hussein, N. Z., Manokaran, N. (2003). Effect of selective logging on canopy and stand structure and tree species composition in a lowland dipterocarp forest in Peninsular Malaysia. Forest Ecology and Management, 175, 297-320. doi:10.1016/S0378-1127(02)00137-8, http://dx.doi.org/10.1016/S0378-1127(02)00137-8

Pickering, C., Hill, W., Green, K. (2008). Vascular plant diversity and climate change in the alpine zone of the Snowy Mountains, Australia. Biodiversity Conservation, 17, 1627-1644. doi:10.1007/s10531-008-9371-y, http://dx.doi.org/10.1007/s10531-008-9371-y

Primack, R. B. and Corlett, R. T. (2005). Tropical rainforests: An ecological and biogeographical comparision. Blackwell Science, Oxford.

Putz, F. E., Holbrook, N. M. (1991). Biomechanical studies of vines. In: F.E. Putz, and H.A. Mooney (Eds). The biology of vines. Cambridge University Press, Cambridge pp. 73-97.

Ruokolainen, K., Tuomisto, H., Vormisto, J. \& Pitman, N. (2002). Two biases in estimating range sizes of Amazonian plant species. Journal of Tropical Ecology, 18, 935-942. doi:10.1017/S0266467402002614, http://dx.doi.org/10.1017/S0266467402002614

Ruokolainen, K. \& Vormisto, J. (2000). The most widespread Amazonian palms tend to be tall and habitat generalists. Basic and Applied Ecology, 1, 97-108. doi:10.1078/1439-1791-00020, http://dx.doi.org/10.1078/1439-1791-00020

Sang, W. (2009). Plant diversity patterns and their relationship with soil and climatic factors along an altitudinal gradient in the middle Tianshan Mountain area, Xinjing, China. Ecol Res., 24, 303-314. doi:10.1007/s11284-008-0507-z, http://dx.doi.org/10.1007/s11284-008-0507-z

Tuomisto, H., Ruokolainen, K., Kalliola, R., Linna, A., Danjoy, W. and Rodriguez, Z. (1995). Dissecting Amazonian biodiversity Science, 269, 63-66. doi:10.1126/science.269.5220.63, http://dx.doi.org/10.1126/science.269.5220.63

Turner, I.M. (1997). A tropical flora summarized - a statistical analysis of the vascular plant density of Malaya. Flora, 192, 157- 163.

Turner, I. M. (1999). A catalogue of the vascular plants of Malaya. The Gardens' Bulletin Singapore, 47, 1-757.

Villasenor, J., Guillermo, I., Meave, J. A., and Eenrique, O. I. (2005). Higher Taxa as Surrogates of Plant Biodiversity in a Megadiverse Country. Conservation Biology, 19(1), 232-238. doi:10.1111/j.1523-1739.2005.00264.x, http://dx.doi.org/10.1111/j.1523-1739.2005.00264.x

Wang, W., Wang, Q., Li, S., Wang, G. (2006). Distribution and species diversity of plant communities along transect on the northeastern Tibetan Plateau. Biodiversity and Conservation, 15, 1811-1828. doi:10.1007/s10531-004-6681-6, http://dx.doi.org/10.1007/s10531-004-6681-6

WWW user survey. Retrived 20 November 20 from http://en.wikipedia.org/wiki/Malaysia/Geography\#climate. 
Table 1. The 20 most abundant species in Sungai Pinang Permanent Forest Reserve in Pulau Pangkor, Perak according to increasing order of IVI

\begin{tabular}{|l|l|l|l|l|l|}
\hline \multicolumn{1}{|c|}{ Family } & \multicolumn{1}{c|}{ Species } & Growth Forms & \multicolumn{1}{c|}{ RDE } & \multicolumn{2}{c|}{ RF } \\
\hline Olacaceae & Strombosia javanica Blume & Tree & 178.09 & 4.8 & 182.89 \\
\hline Juglandaceae & Engelhardtia serrata Blume & Tree & 194.91 & 5.29 & 200.2 \\
\hline Palmae & Daemonorops calicarpa (Griff.) Mart. & Palm & 205.83 & 5.908 & 211.74 \\
\hline Ebenaceae & Diospyros buxifolia (Blume) Hiern & Tree & 222 & 6.69 & 228.69 \\
\hline Leguminosae & Dalbergia parviflora Roxb. & Liana & 229.36 & 7.26 & 236.62 \\
\hline Ulmaceae & Girroniera parvifolia Planch. & Tree & 244.25 & 6.63 & 250.88 \\
\hline Dipterocarpaceae & Shorea curtisii Dyer ex King & Tree & 274.83 & 8.27 & 283.1 \\
\hline Dracaenaceae & Dracaena elliptica Thunb. & Shrub & 284.44 & 7.08 & 291.52 \\
\hline Dipterocarpaceae & Vatica pauciflora (Korth.) Blume & Tree & 286.53 & 8.12 & 294.65 \\
\hline Palmae & Calamus javensis Blume & Palm & 288.95 & 8 & 296.95 \\
\hline Aristolochiaceae & Thottea corymbosa (Griff.) Ding Hou & Tree & 309.97 & 7.78 & 317.75 \\
\hline Leguminosae & Fordia unifoliata (Prain) Dasuki \& Schot & Tree & 328.21 & 9.87 & 338.08 \\
\hline Dipterocarpaceae & Vatica perakensis King & Tree & 353.7 & 11.79 & 365.49 \\
\hline Anacardiaceae & Swintonia floribunda Griff. & Tree & 434.96 & 15.15 & 450.11 \\
\hline Polygalaceae & Xanthophyllum affine Korthalsia & Tree & 461.06 & 13.8 & 474.86 \\
\hline Dracaenaceae & Dracaena graminifolia Wall & Shrub & 587.53 & 14.98 & 602.51 \\
\hline Dracaenaceae & Dracaena pendula Ridley & Shrub & 749.32 & 20.8 & 770.12 \\
\hline Polypodiaceae & Taenitis blechnoides (Willd.) Sw & Fern & 759.8 & 23.78 & 783.58 \\
\hline Guttiferae & Calophyllum wallichianum Planch.\&Triana & Tree & 785.78 & 21.05 & 806.83 \\
\hline Palmae & Eugeissona tristis Griff. & Palm & 861 & 29.38 & 890.38 \\
\hline Euphorbiaceae & Agrostistachys longifolia (Wight) Benth. & Tree & 1202 & 42.82 & 1244.82 \\
\hline
\end{tabular}

Table 2. The 20 least abundant species in Sungai Pinang Permanent Forest Reserve in Pulau Pangkor, Perak according to increasing order of IVI

\begin{tabular}{|l|l|l|l|l|l|}
\hline Family & Species & Growth form & \multicolumn{1}{|l|}{ RDE } & \multicolumn{3}{|c|}{ RF } \\
\hline Araceae & Alocasia denudata Endl. & Herb & 0.32 & 0.007 & 0.327 \\
\hline Rubiaceae & Argostemma oblongum King & Herb & 0.32 & 0.007 & 0.327 \\
\hline Zingiberaceae & Globba pendula Roxb. & Herb & 0.32 & 0.007 & 0.327 \\
\hline Araceae & Schismatoglottis brevipes Hook.f. & Herb & 0.32 & 0.007 & 0.327 \\
\hline Araceae & Schismatoglottis wallichii Hook.f. & Herb & 0.32 & 0.007 & 0.327 \\
\hline Asteraceae & Vernonia arborea Buch. Hamrborea & Herb & 0.32 & 0.007 & 0.327 \\
\hline Lauraceae & Actinodaphne oleifolia Gamble & Shrub & 0.32 & 0.007 & 0.327 \\
\hline Ochnaceae & Euthemis leucocarpa Jack & Shrub & 0.32 & 0.007 & 0.327 \\
\hline Olacaceae & Olax imbricata Roxb. & Shrub & 0.32 & 0.007 & 0.327 \\
\hline Meliaceae & Chisocheton pauciflorus King & Tree & 0.32 & 0.007 & 0.327 \\
\hline Meliaceae & Chukrasia tabularis Ridley & Tree & 0.32 & 0.007 & 0.327 \\
\hline Celastraceae & Euonymus javanicus Blume & Tree & 0.32 & 0.007 & 0.327 \\
\hline Moraceae & Ficus aurata Miq. & Tree & 0.32 & 0.007 & 0.327 \\
\hline Rhizophoraceae & Gynotroches axillaris Blume & Tree & 0.32 & 0.007 & 0.327 \\
\hline Sterculiaceae & Pterospermum javanicum Jungh. & Tree & 0.32 & 0.007 & 0.327 \\
\hline Cardiopteridaceae & Cardiopteris quinqueloba (Hassk.) Hassk & Climber & 0.32 & 0.007 & 0.327 \\
\hline Annonaceae & Ellipeia cuneifolia Hook.f. \& Thomson & Liana & 0.32 & 0.008 & 0.328 \\
\hline Anacardiaceae & Gluta curtisii (Oliv.) Ding Hou & Tree & 0.32 & 0.008 & 0.328 \\
\hline Poaceae & Schizostachyum latifolium Gamble & Bamboo & 0.42 & 0.009 & 0.429 \\
\hline Lauraceae & Alseodaphne sp. & Tree & 0.42 & 0.009 & 0.429 \\
\hline Boraginaceae & Cordia dichotoma G. Forst. & Tree & 0.42 & 0.009 & 0.429 \\
\hline
\end{tabular}

$\mathrm{RDE}=$ relative density, $\mathrm{RF}=$ Relative frequency, IVI=Importance Value Index 
Table 3. The number of species and individuals according to growth form in five 1-ha plot in Sungai Pinang Permanent Forest Reserve in Pulau Pangkor, Perak

\begin{tabular}{|l|c|c|}
\hline Growth-forms & Species numbers & Plants numbers in 5 plots \\
\hline Epiphyte & 3 & 21 \\
\hline Climber & 12 & 745 \\
\hline Herb & 31 & 3420 \\
\hline Liana & 32 & 1634 \\
\hline Terrestrial & 12 & 2354 \\
\hline Palm & 14 & 3546 \\
\hline Shrub & 44 & 5477 \\
\hline Tree & 200 & 19600 \\
\hline Total & $\mathbf{3 4 8}$ & $\mathbf{3 6 7 9 7}$ \\
\hline
\end{tabular}

Table 4. The percentage of medicinal and endemic species between growth-forms in five 1-ha plot in Sungai Pinang Permanent Forest Reserve in Pulau Pangkor, Perak

\begin{tabular}{|l|c|c|c|c|}
\hline \multicolumn{1}{|c|}{ Growth-forms } & Medicinal Sp. & Percentage & Endemic Sp. & Percentage \\
\hline Epiphyte & 2 & $1.65 \%$ & 1 & $1.8 \%$ \\
\hline Climber & 5 & $4.10 \%$ & 1 & $1.8 \%$ \\
\hline Herb & 11 & $9.10 \%$ & 7 & $12.7 \%$ \\
\hline Liana & 15 & $12.30 \%$ & 4 & $7.3 \%$ \\
\hline Terrestrial & 4 & $3.30 \%$ & - & - \\
\hline Palm & 1 & $0.80 \%$ & 6 & $10.9 \%$ \\
\hline Shrub & 24 & $20 \%$ & 8 & $14.5 \%$ \\
\hline Tree & 59 & $49 \%$ & 28 & $51 \%$ \\
\hline Total & $\mathbf{1 2 7}$ & $\mathbf{1 0 0}$ & $\mathbf{5 5}$ & $\mathbf{1 0 0}$ \\
\hline
\end{tabular}

Table 5. The result of ANOVA and linear regression of growth-forms against elevation $\mathbf{B}_{\mathbf{0}}$

$\mathbf{B}_{1}$

\begin{tabular}{|l|l|l|l|l|l|l|l|l|}
\hline Growth-form & Estimate & $\begin{array}{c}\text { Std. } \\
\text { Error }\end{array}$ & $\begin{array}{c}\text { Confidence } \\
\text { Interval (0.95\%) }\end{array}$ & Estimate & Std. Error & $\begin{array}{c}\text { Confidence Interval } \\
\mathbf{( 0 . 9 5 \% )}\end{array}$ & P Value & \\
\hline Climber & 8.047 & 30.847 & 106.215 & 0.129 & 0.276 & 1.008 & 0.67 & 0.067 \\
\hline Epiphyte & 531.651 & 153.189 & 1019.165 & -3.78 & 1.373 & 0.581 & -1.42 & 0.07 \\
\hline Herb & 903.451 & 168.76 & 1440.54 & -6.24 & 1.51 & -717 \\
\hline Liana & 1509.91 & 312.95 & 2505.87 & -8.995 & 2.8 & -0.071 & $0.02 *$ & 0.85 \\
\hline Palm & 2930.44 & 639.39 & 4965.27 & -15.85 & 5.729 & 2.38 & $0.049 *$ & 0.774 \\
\hline Shrub & 760.501 & 348.46 & 1869.47 & -1.351 & 3.123 & 8.58 & 0.07 & 0.718 \\
\hline Fern & 8657.18 & 1350.96 & 12956.54 & -59.99 & 12.10 & -21.464 & 0.69 & 0.059 \\
\hline Tree & 15128.64 & 2396.95 & 22756.83 & -84.50 & 21.479 & -16.148 & $0.01 *$ & 0.891 \\
\hline
\end{tabular}

Table 6. Species diversity indices based on five 1-ha sampling plots in Sungai Pinang Permanent Forest Reserve in Pulau Pangkor, Perak

\begin{tabular}{|c|c|c|c|c|c|c|}
\hline Plot & Alpha Fisher & Shannon-Wienner & Simpson & Jack 2 & Chao 2 & Simpson evenness \\
\hline Plot 1 & 51.38 & 4.98 & 45.43 & 329.67 & 303.11 & 0.71 \\
\hline Plot 2 & 35.11 & 4.01 & 30.52 & 234.79 & 214.73 & 0.19 \\
\hline Plot 3 & 25.46 & 3.54 & 19.48 & 167.84 & 152.22 & 0.21 \\
\hline Plot 4 & 30.55 & 3.84 & 24.58 & 208.9 & 189.84 & 0.2 \\
\hline Plot 5 & 33.67 & 3.57 & 18.09 & 161.13 & 147.66 & 0.17 \\
\hline Average & $\mathbf{3 5 . 2 3}$ & $\mathbf{3 . 9 9}$ & $\mathbf{2 7 . 6 2}$ & $\mathbf{2 2 0 . 4 6}$ & $\mathbf{2 0 1 . 5 1}$ & $\mathbf{0 . 3}$ \\
\hline
\end{tabular}




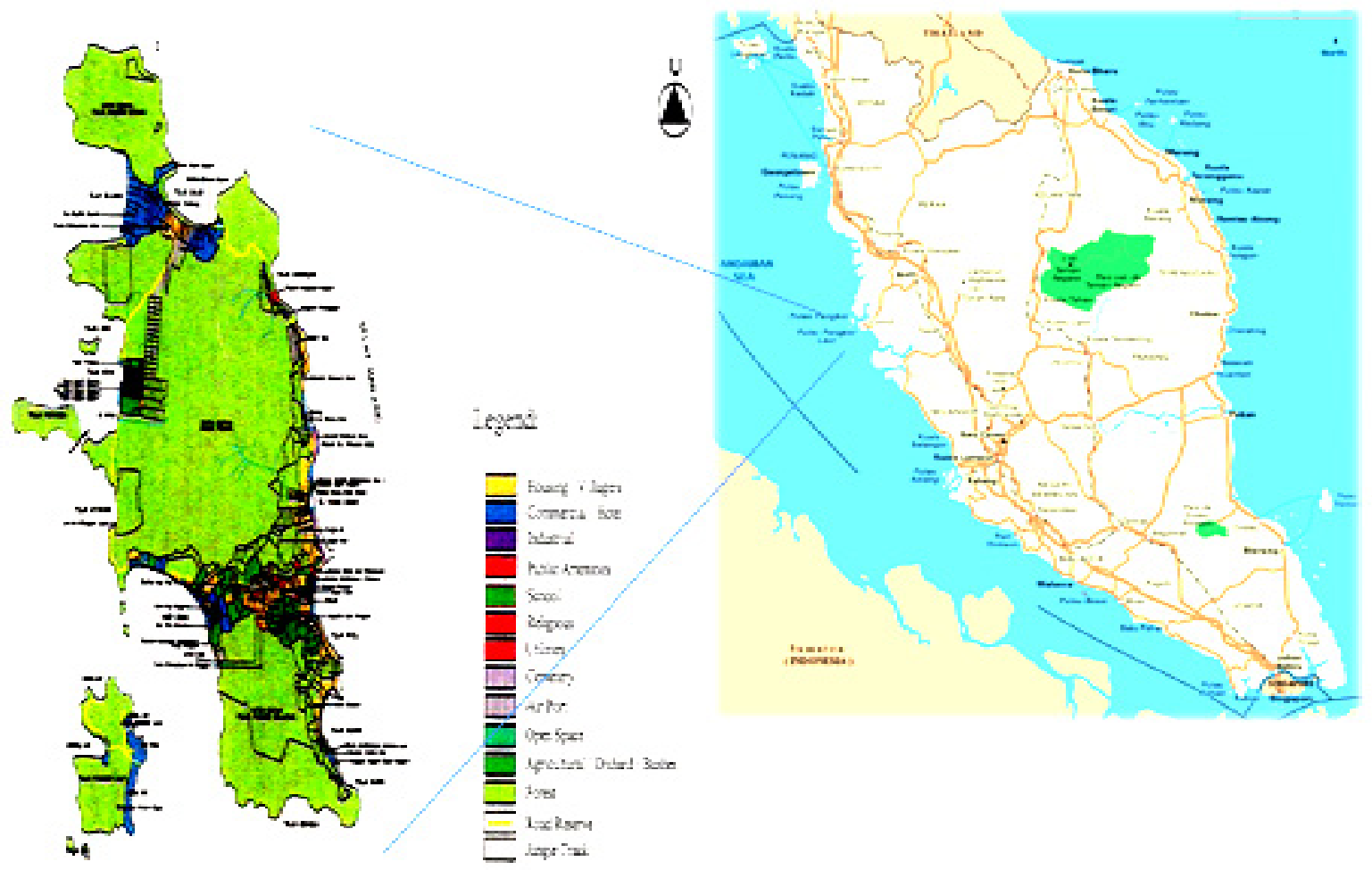

Figure 1. Map of Peninsular Malaysia and location of study area in Pulau Pangkor

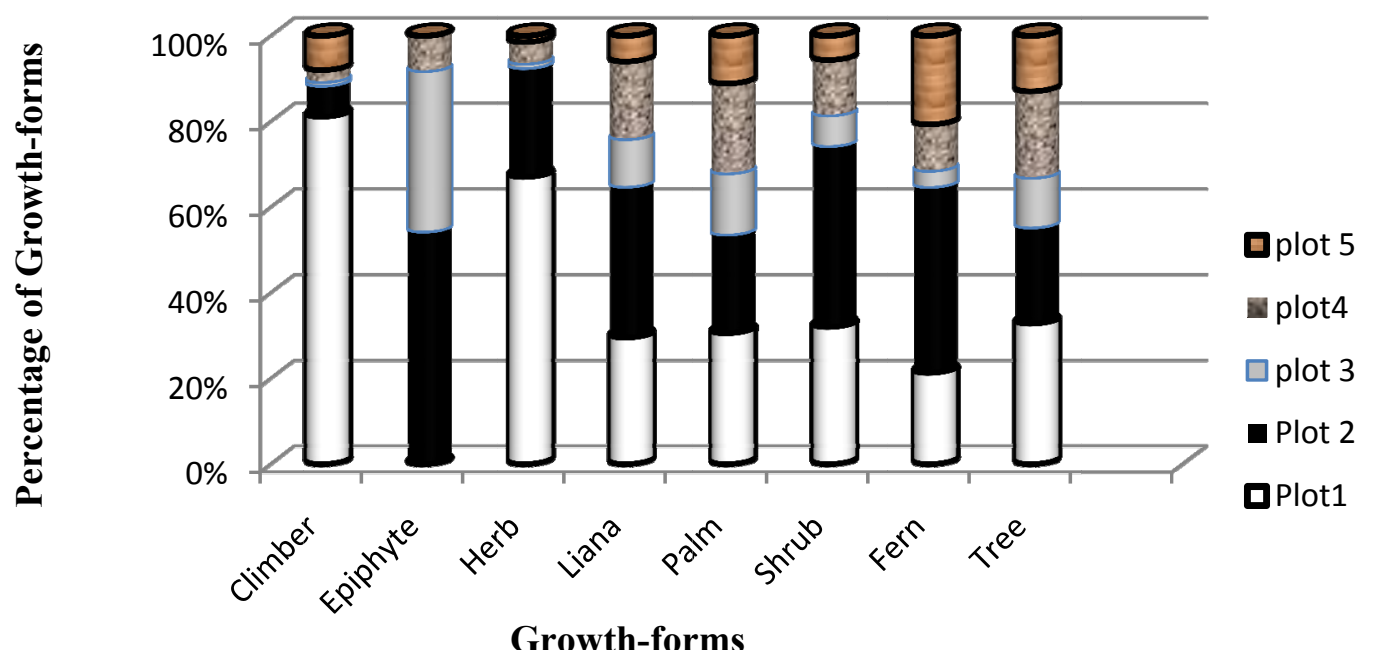

Figure 2. The percentage of growth-forms in five 1-ha plots in Sungai Pinang Permanent Forest Reserve in Pulau Pangkor, Perak 


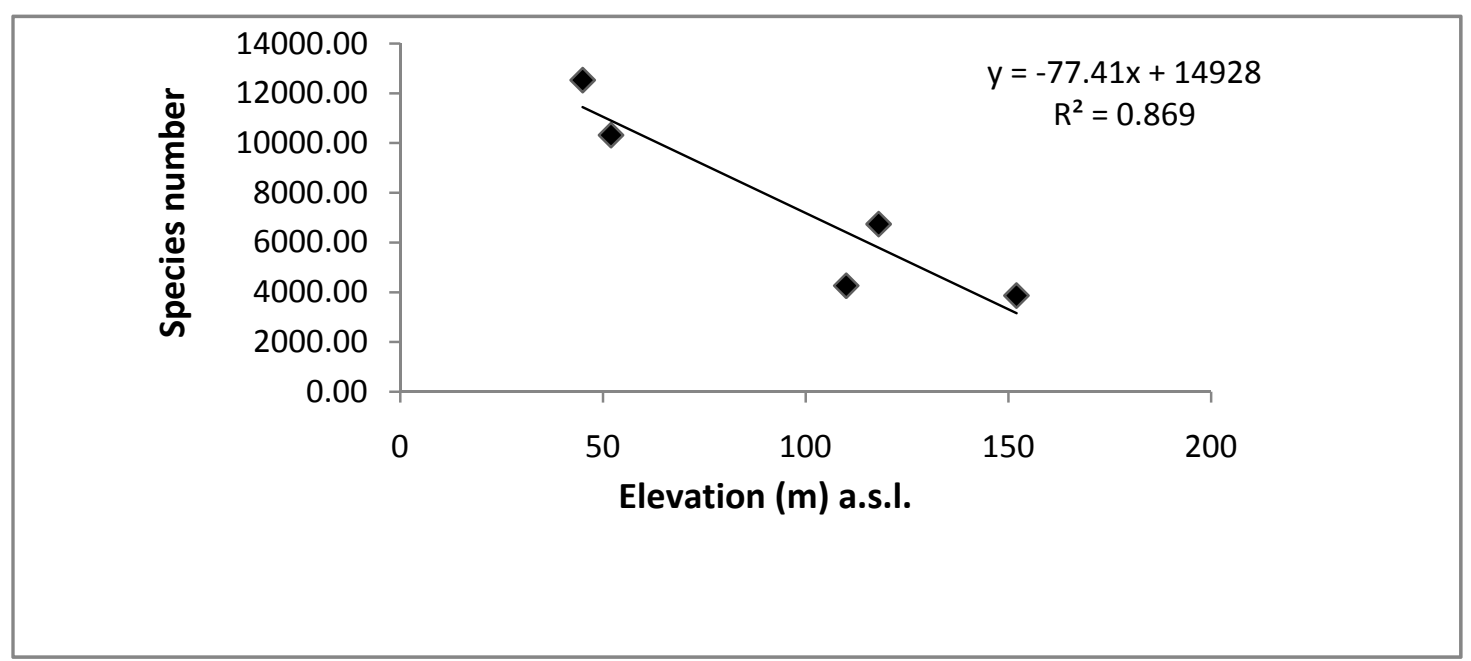

Figure 3. The regression of species number trend with elevation in Pulau Pangkor

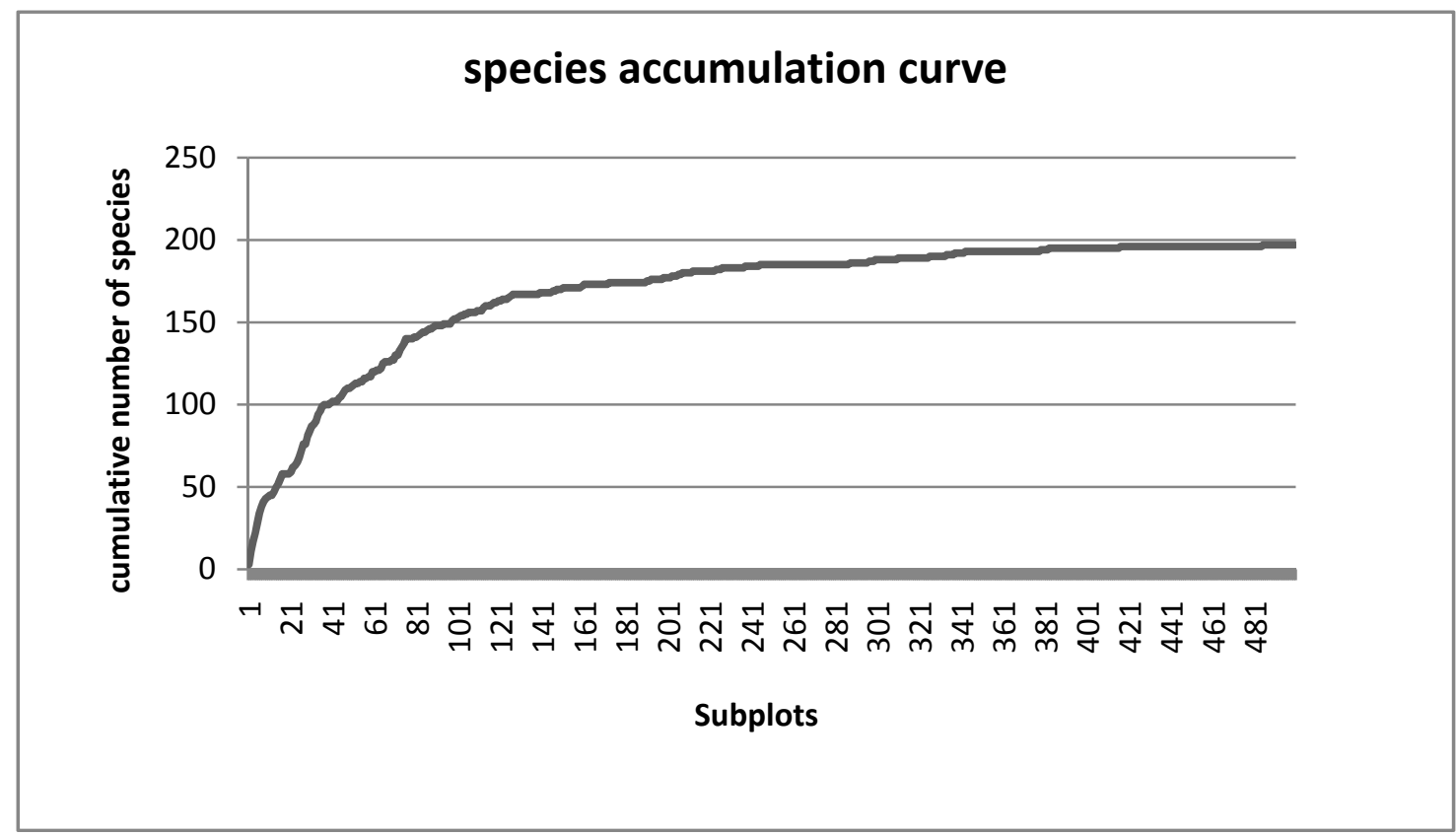

Figure 4. Species accumulation curve based on a cumulative species count in $10 \times 10 \mathrm{~m}$ plots of a five 1-ha plot in Sungai Pinang Permanent Forest Reserve in Pulau Pangkor, Perak 
Appendix 1. Total list of species in five 1-ha plots in Sungai Pinang Permanent Forest Reserve in Pulau Pangkor, Perak

Family

Acanthaceae

Acanthaceae

Anacardiaceae

Anacardiaceae

Anacardiaceae

Anacardiaceae

Anacardiaceae

Anacardiaceae

Anacardiaceae

Anisophylleaceae

Anisophylleaceae

Annonaceae

Annonaceae

Annonaceae

Annonaceae

Annonaceae

Annonaceae

Annonaceae

Apocynaceae

Apocynaceae

Apocynaceae

Araceae

Araceae

Araceae

Araceae

Araceae

Araceae

Araceae

Araceae

Araceae

Araceaelidiaceae

Araliaceae

Araliaceae

Araucariaceae

Aristolochiaceae

Asteraceae

Asteraceae

Blechnaceae

Blechnaceae

Boraginaceae

Burseraceae

Burseraceae

Burseraceae

Burseraceae

Cardiopteridaceae

Celastraceae

Celastraceae

Celastraceae

Combretaceae

Combretaceae

Commelinaceae

Connaraceae

Connaraceae

Connaraceae

Connaraceae
Species

Gymnostachyum decurrens Stap

Staurogyne merguensis (T. Anderson) Kuntze

Bouea oppositifolia (Roxb.) Meisn.

Buchanania sessifolia Blume

Gluta curtisii (Oliv.) Ding Hou

Mangifera macrocarpa Blume

Mangifera sp.

Swintonia floribunda Griff.

Swintonia spicifera Hook

Anisophyllea grandis (Benth.) Burkill

Anisophyllea scortechinii King

Uvaria grandiflora Roxb. ex Hornem

Artabotrys suaveolens (Blume) Blume

Ellipeia cuneifolia Hook.f. \& Thomson

Mitrella kentii (Blume) Miq. Pyramidanthe prismatica (Hook.f. \& Thomson)

Polyalthia glauca (Hassk.) F. Muell

Polyalthia hypoleuca Hook.f. \& Thomson

Willughbeia edulis Roxb.

Alstonia angustiloba Miq.

Dyera costulata (Miq.) Hook.f.

Epipremnum giganteum (Roxb.) Schott

Pothos kingii Hook.f

Scindapsus perakensis Hook.f.

Aglaonema simplex Blume

Schismatoglottis brevipes Hook

Schismatoglottis wallichii Hook.f.

Homalomena humilis (Jack) Hook.f.

Scindapsus scortechinii Hook.f.

Alocasia denudata Endl. var. denudata

Aralidium pinnatifitidum (Jungh. \& de Vriese) Miq.

Schefflera ridleyi (King) R. Vig.

Arthrophyllum diversifolium Blume

Agathis borneensis Warb.

Thottea corymbosa (Griff.) Ding Hou

Adenostemma viscosum J.R. Forst. \& G. Forst.

Vernonia arborea Buch. Hamrborea

Blechnum finlaysonianum Wall. ex Hook. \& Grev.

Blechnum orientale $\mathrm{L}$.

Cordia dichotoma $G$. Forst.

Canarium littorale Blume

Canarium pilosum Benn.

Dacryodes laxa (Benn.) H.J. Lam

Santiria apiculata Benn.

Cardiopteris quinqueloba (Hassk.) Hassk

Bhesa paniculata Arn.

Euonymus javanicus Blume

Lophopetalum sp.

Combretum nigrescens King

Combretum sundaicum Miq.

Commelina benghalensis L.

Agelaea borneensis (Hook.f.) Merr.

Connarus semidecandrus Jack

Connarus ferrugineus Jack

Connarus grandis Jack
Growth-Form ndemic Sp. Medicinal Sp.

Herb

Herb

Tree

Tree

Tree

Tree

Tree

Tree

Tree
Tree

Tree

Climber

Liana

Liana

Liana

Liana

Tree

Tree

Liana

Tree

Tree

Climber

Climber

Climber

Herb

Herb

Herb

Herb

Liana

Shrub

Small Tree

Shrub

Tree

Tree

shrub

Herb

Tree

Fern

Fern

Tree

Tree

Tree

Tree

Tree

Small Tree

Tree

Tree

Tree

Liana

Liana

Herb

Liana

Shrub

Small Tree

Small tree

Medicinal

Medicinal

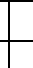

Medicinal

Medicinal

\begin{tabular}{|l|l|}
\hline Endemic & \\
\hline & \\
\hline Endemic & \\
\hline & \\
\hline
\end{tabular}

Endemic

Medicinal

\begin{tabular}{|l|l|}
\hline & Medicinal \\
\hline & \\
\hline & \\
\hline & \\
\hline
\end{tabular}

Medicinal

\begin{tabular}{|c|c|}
\hline & Medicinal \\
\hline & \\
\hline & \\
\hline & Medicinal \\
\hline & \\
\hline & \\
\hline & \\
\hline & \\
\hline & Medicinal \\
\hline & Medicinal \\
\hline & Medicinal \\
\hline & Medicinal \\
\hline Endemic & Medicinal \\
\hline & \\
\hline & Medicinal \\
\hline & \\
\hline & Medicinal \\
\hline & \\
\hline & Medicinal \\
\hline & \\
\hline & \\
\hline & \\
\hline & \\
\hline & \\
\hline & \\
\hline & \\
\hline & Medicinal \\
\hline & Medicinal \\
\hline & \\
\hline & \\
\hline & \\
\hline Endemic & \\
\hline
\end{tabular}




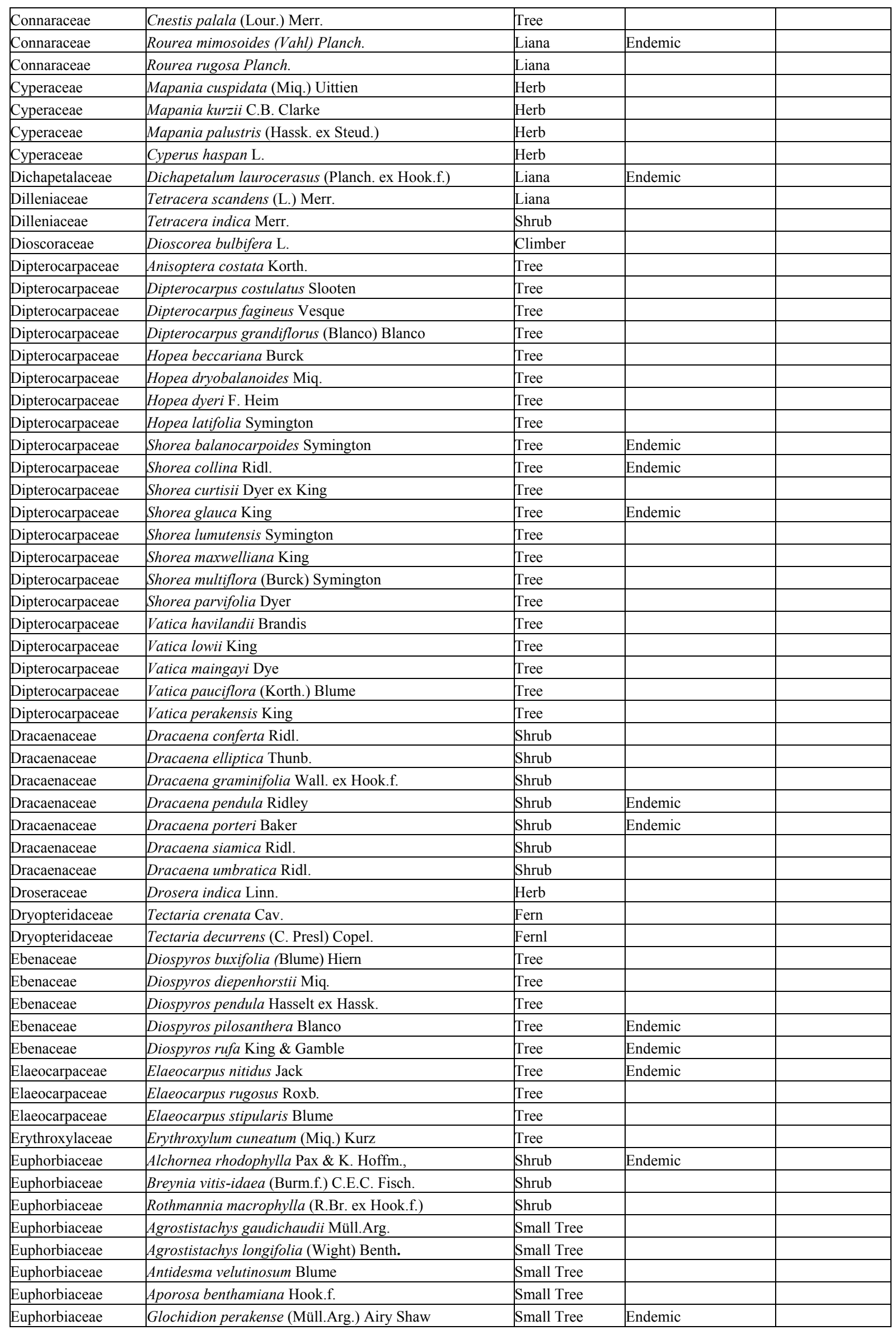




\begin{tabular}{|c|c|c|c|c|}
\hline Euphorbiaceae & Aporosa arborea (Blume) Müll.Arg. & Tree & & \\
\hline Euphorbiaceae & Aporosa nervosa Hook.f. & Tree & Endemic & \\
\hline Euphorbiaceae & Botryophora geniculata (Miq.) Beumée ex Airy & Tree & & \\
\hline Euphorbiaceae & Cleistanthus glaucus Jabl. & Tree & Endemic & \\
\hline Euphorbiaceae & Cleistanthus hirsutulus Hook.f. & Tree & & \\
\hline Euphorbiaceae & Cleistanthus macrophyllus Hook.f. & Tree & & \\
\hline Euphorbiaceae & Elateriospermum tapos Blume & Tree & & \\
\hline Euphorbiaceae & Endospermum diadenum (Miq.) Airy Shaw & Tree & & \\
\hline Euphorbiaceae & Macaranga hullettii King ex Hook.f. & Tree & & \\
\hline Euphorbiaceae & Mallotus penangensis Müll.Arg. & Tree & & \\
\hline Euphorbiaceae & Mallotus subpeltatus (Blume) Müll.Arg. & Tree & & \\
\hline Euphorbiaceae & Phyllanthus emblica $\mathrm{L}$. & Tree & Endemic & \\
\hline Leguminosae & Bauhinia kockiana Korthalsia & Liana & & \\
\hline Leguminosae & Dalbergia parviflora Roxb. & Liana & & \\
\hline Leguminosae & Spatholobus ferrugineus (Zoll. \& Moritzi) Benth. & Liana & & \\
\hline Leguminosae & Millettia dasyphylla (Miq.) Boerl. & Small Tree & & \\
\hline Leguminosae & Adenanthera malayana Kosterm. & Tree & & \\
\hline Leguminosae & Callerya atropurpurea (Wall.) Schot & Tree & & \\
\hline Leguminosae & Dialium platysepalum Baker & Tree & & \\
\hline Leguminosae & Fordia unifoliata (Prain) Dasuki \& Schot & Tree & & \\
\hline Leguminosae & Saraca indica $\mathrm{L}$. & Tree & & \\
\hline Leguminosae & Fordia pauciflora Dunn & Treetlet & Endemic & \\
\hline Fagaceae & Lithocarpus cantleyanus (King ex Hook.f.) Rehder & Tree & & \\
\hline Fagaceae & Lithocarpus wallichianus (Lindl. ex Hance) Rehder & Tree & & \\
\hline Flacourtiaceae & Casearia latifolia Ridl. & Small Tree & & \\
\hline Flacourtiaceae & Casearia velutinosa Ridl. & Small Tree & & \\
\hline Flacourtiaceae & Casearia clarkei King & Tree & Endemic & \\
\hline Flacourtiaceae & Flacourtia rukam Zoll. \& Moritzi & Small tree & Endemic & \\
\hline Flacourtiaceae & Hydnocarpus curtisii King & Tree & & \\
\hline Flacourtiaceae & Ryparosa javanica Kurz ex Koord. & Tree & & \\
\hline Flacourtiaceae & Ryparosa kunstleri King & Tree & & \\
\hline Gesneriaceae & Cyrtandra cupulata Ridl. & Herb & Endemic & \\
\hline Gesneriaceae & Didymocarpus platypus C.B. Clarke & Herb & & \\
\hline Gesneriaceae & Didymocarpus sp. & Herb & Endemic & \\
\hline Gesneriaceae & Cyrtandra wallichii (C.B. Clarke) B.L. Burtt & Shrub & & \\
\hline Gnetaceae & Gnetum microcarpum Blume & Liana & & \\
\hline Gnetaceae & Gnetum gnemon L. & Shrub & & \\
\hline Guttiferae & Calophyllum calaba $\mathrm{L}$. & Tree & & Medicinal \\
\hline Guttiferae & Calophyllum molle King & Tree & & Medicinal \\
\hline Guttiferae & Calophyllum wallichianum Planch. \& Triana & Tree & Endemic & Medicinal \\
\hline Guttiferae & Garcinia atroviridis Griff. ex T. Anderson & Tree & Medicinal & \\
\hline Guttiferae & Garcinia griffithii T. Anderson & Tree & & Medicinal \\
\hline Guttiferae & Garcinia nigrolineata Planch. ex T. Anderson & Tree & & Medicinal \\
\hline Guttiferae & Garcinia scortechinii King & Tree & & Medicinal \\
\hline Guttiferae & Mesua daphnifolia (Ridl.) Kosterm. & Tree & & Medicinal \\
\hline Guttiferae & Mesua ferrea $\mathrm{L}$ & Tree & & Medicinal \\
\hline Hydrocharitaceae & Enhalus acoroides (L.f.) Royle & Herb & & \\
\hline Hypoxidaceae & Molineria latifolia (Dryand.) Herb. ex Kurz & Herb & & \\
\hline Ixonanthaceae & Ixonanthes reticulata Jack & Tree & & \\
\hline Juglandaceae & Engelhardtia serrata Blume & Tree & & \\
\hline Lauraceae & Actinodaphne oleifolia Gamble & Shrub & & \\
\hline Lauraceae & Alseodaphne sp. & Tree & & \\
\hline Lauraceae & Cinnamomum iners Reinw & Tree & & \\
\hline Lauraceae & Dehaasia cuneata (Blume) Blume & Tree & & \\
\hline Lauraceae & Dehaasia polyneura (Miq.) Kosterm & Tree & & \\
\hline Lauraceae & Litsea myristicifolia (Wall. ex Nees) Hook.f. & Tree & & \\
\hline Lauraceae & Litsea nidularis Gamble & Tree & & \\
\hline Lauraceae & Persea declinata (Blume) Kosterm. & Tree & & \\
\hline Lecythidaceae & Barringtonia pendula (Griff.)Kurz & Tree & & \\
\hline
\end{tabular}




\begin{tabular}{|c|c|c|c|c|}
\hline Linaceae & Roucheria griffithiana Planch. & Liana & & \\
\hline Loganiaceae & Strychnos axillaris Colebr. & Liana & & \\
\hline Loganiaceae & Strychnos flavescens King \&Gamble & Liana & & \\
\hline Loranthaceae & Scurrula parasitica $\mathrm{L} . \quad \quad-$ & Shrub & & \\
\hline Melastomataceae & Sonerila caesia Stapf & Herb & Endemic & \\
\hline Melastomataceae & Clidemia hirta (L.) D. Don & Shrub & & \\
\hline Melastomataceae & Melastoma muticum Ridl., & Shrub & & \\
\hline Melastomataceae & Lijndenia laurina Zoll. \& Moritzi & Small tree & & \\
\hline Melastomataceae & Memecylon minutiflorum Miq. & Tree & Endemic & \\
\hline Melastomataceae & Pternandra coerulescens Jack & Tree & & \\
\hline Meliaceae & Aglaia argentea Blume & Tree & & \\
\hline Meliaceae & Aglaia leptantha Miq. & Tree & & \\
\hline Meliaceae & Aglaia leucophylla King & Tree & & \\
\hline Meliaceae & Chisocheton pauciflorus King & Tree & Endemic & \\
\hline Meliaceae & Chukrasia tabularis Ridley & Tree & & \\
\hline Meliaceae & Dysoxylum arborescens (Blume) Miq. & Tree & & \\
\hline Meliaceae & Dysoxylum rigidum (Ridl.) Mabb. & Tree & & \\
\hline Meliaceae & Pseudoclausena chrysogyne (Miq.) T.P. Clark & Tree & & \\
\hline Meliaceae & Sandoricum koetjape (Burm.f.) Merr & Tree & & \\
\hline Meliaceae & Toona sureni (Blume) Merr. & Tree & & \\
\hline Meliaceae & Walsura pinnata Hassk & Tree & & \\
\hline Menispermaceae & Coscinium blumeanum Miers ex Hook.f. \& Thomson & Liana & & \\
\hline Menispermaceae & Coscinium fenestratum (Gaertner) Colebr. & Liana & & \\
\hline Menispermaceae & Diploclisia kunstleri (King) Diels & Liana & & \\
\hline Menispermaceae & Fibraurea tinctoria Lour. & Liana & Endemic & \\
\hline Menispermaceae & Tinomiscium petiolare Hook.f. \& Thomson & Liana & & \\
\hline Moraceae & Ficus bracteata Wall. ex Miq. & Liana & & \\
\hline Moraceae & Ficus punctata Thunb & Liana & & \\
\hline Moraceae & Ficus aurata Miq. & Shrub & & \\
\hline Moraceae & Artocarpus lanceifolius Roxb. & Tree & & \\
\hline Moraceae & Artocarpus nitidus Trécul & Tree & & \\
\hline Moraceae & Streblus elongatus (Miq.) Corner. & Tree & & \\
\hline Moraceae & Streblus ilicifolius (Vidal) Corner & Tree & & \\
\hline Myristicaceae & Horsfieldia polyspherula (Hook.f.) J. Sinclair & Tree & & \\
\hline Myristicaceae & Knema furfuracea (Hook.f. \& Thomson) Warb. & Tree & & \\
\hline Myristicaceae & Knema hookeriana (Wall. ex Hook.f. \& Thomson) & Tree & & \\
\hline Myristicaceae & Knema malayana Warb & Tree & & \\
\hline Myristicaceae & Myristica cinnamomea King & Tree & & \\
\hline Myristicaceae & Myristica maxima Warb. & Tree & & \\
\hline Myrsinaceae & Ardisia oxyphylla Wall. ex A. DC. & Shrub & & \\
\hline Myrsinaceae & Ardisia pachysandra (Wall. ex Roxb.) Mez & Shrub & & \\
\hline Myrsinaceae & Ardisia lanceolata Roxb. & Tree & & \\
\hline Myrtaceae & Syzygium chloroleucum (King) Masam. & Shrub & & \\
\hline Myrtaceae & Eugenia sp.9 & Tree & & \\
\hline Myrtaceae & Syzygium acuminatissimum (Blume) DC & Tree & & \\
\hline Myrtaceae & Syzygium claviflorum (Roxb.) Wall. ex A.M. Cowan & Tree & Endemic & \\
\hline Myrtaceae & Syzygium linoceroides (King) I.M. & Tree & Endemic & \\
\hline Myrtaceae & Rhodamnia cinerea Ridl. & Tree & & Medicinal \\
\hline Ochnaceae & Euthemis leucocarpa Jack & Shrub & & Medicinal \\
\hline Ochnaceae & Ochna integerrima (Lour.) Merr. & Small Tree & & \\
\hline Ochnaceae & Brackenridgea hookeri (Planch.) A. Gray & Tree & & \\
\hline Ochnaceae & Campylospermum serratum (Gaertn.) Bittrich & Tree & & \\
\hline Ochnaceae & Gomphia microphylla Ridl. & Tree & & Medicinal \\
\hline Olacaceae & Olax imbricata Roxb. & Climber & & \\
\hline Olacaceae & Ximenia americana $\mathrm{L}$. & Small Tree & & Medicinal \\
\hline Olacaceae & Scorodocarpus borneensis (Baill.) Becc. & Tree & & Medicinal \\
\hline Olacaceae & Strombosia ceylanica Gardn. & Tree & & \\
\hline Olacaceae & Strombosia javanica Blume & Tree & & \\
\hline Olacaceae & Strombosia maingayi Whitmore & Tree & & \\
\hline
\end{tabular}




\begin{tabular}{|c|c|c|c|c|}
\hline Orchidaceae & Vanilla griffithii Rchb.f. & Climber & & Medicinal \\
\hline Orchidaceae & Appendicula anceps Blume & Epiphyte & & \\
\hline Orchidaceae & Epigeneium zebrinum (J.J.Sm.) Summerh. & Epiphyte & & Medicinal \\
\hline Orchidaceae & Grammatophyllum speciosum Blume & Epiphyte & Endemic & Medicinal \\
\hline Orchidaceae & Cryptostylis arachnites (Blume) Hassk. & Herb & & \\
\hline Oxalidaceae & Averrhoa bilimbi L. & Tree & & Medicinal \\
\hline Oxalidaceae & Sarcotheca griffithii (Planch. ex Hook.f.) Hallier f. & Tree & Endemic & \\
\hline Palmae & Arenga westerhoutii Griff. & Palm & & \\
\hline Palmae & Calamus castaneus Griff. & Palm & & \\
\hline Palmae & Calamus insignis Griff. & Palm & Endemic & \\
\hline Palmae & Calamus javensis Blume & Palm & & \\
\hline Palmae & Daemonorops calicarpa (Griff.) Mart. & Palm & & \\
\hline Palmae & Eugeissona brachystachys Ridl. & Palm & Endemic & \\
\hline Palmae & Eugeissona tristis Griff. & Palm & Endemic & \\
\hline Palmae & Korthalsia rigida Blume & Palm & Endemic & \\
\hline Palmae & Korthalsia scortechinii Becc. & Palm & & \\
\hline Palmae & Licuala kingiana Becc. & Palm & & \\
\hline Palmae & Licuala spinosa Wurmb. Verh. & Palm & & \\
\hline Palmae & Oncosperma horridum (Griff.) Scheff.Bayas & Palm & & Medicinal \\
\hline Palmae & Pinanga perakensis Becc. & Palm & Endemic & \\
\hline Palmae & Pinanga subruminata Becc. & Palm & Endemic & \\
\hline Pandaceae & Microdesmis caseariifolia Planch. & Shrub & & \\
\hline Pandaceae & Pandanus humilis Lour. & Shrub & Endemic & Medicinal \\
\hline Pandaceae & Pandanus prainii Martelli & Shrub & & Medicinal \\
\hline Pandaceae & Galearia fulva (Tul.) Miq. & Tree & & \\
\hline Passifloraceae & Adenia penangiana (Wall. ex G. Don) W.J. de Wilde & Cimber & & Medicinal \\
\hline Pentaphragmaceae & Pentaphragma horsfieldii (Miq.) Airy Shaw & Herb & & \\
\hline Piperaceae & Piper magnibaccum C. DC. & Climber & & Medicinal \\
\hline Poaceae & Schizostachyum latifolium Gamble & Herb & & \\
\hline Polygalaceae & Polygala polifolia Presl & Herb & Endemic & \\
\hline Polygalaceae & Xanthophyllum affine Korthalsia & Tree & & Medicinal \\
\hline Polygalaceae & Xanthophyllum amoenum Chodat & Tree & & \\
\hline Polygalaceae & Xanthophyllum ellipticum Korth. ex Miq. & Tree & & \\
\hline Polygalaceae & Xanthophyllum eurhynchum Miq. & Tree & & \\
\hline Polygalaceae & Xanthophyllum flavescens Roxb. & Tree & & \\
\hline Polygalaceae & Xanthophyllum griffithii Hook.f. ex A.W. Benn & Tree & & \\
\hline Polypodiaceae & Taenitis blechnoides (Willd.) Sw & Fern & & \\
\hline Polypodiaceae & Taenitis interrupta Hook. \& Grev & Fern & & \\
\hline Polypodiaceae & Pyrrosia piloselloides (L.) M.G. Price & Fern & & \\
\hline Rhamnaceae & Ventilago malaccensis Ridl. & Climber & & \\
\hline Rhizophoraceae & Gynotroches axillaris Blume & Small Tree & Endemic & Medicinal \\
\hline Rhizophoraceae & Pellacalyx saccardianus Scort. & Tree & & \\
\hline Rubiaceae & Paederia foetida $\mathrm{L}$. & Climber & & Medicinal \\
\hline Rubiaceae & Argostemma oblongum King & Herb & Endemic & \\
\hline Rubiaceae & Argostemma elatostemma Hook.f. & Herb & & Medicinal \\
\hline Rubiaceae & Coptosapelta griffithii Hook.f. & Liana & & Medicinal \\
\hline Rubiaceae & Oxyceros curtisii (King \& Gamble) K.M. Wong & Liana & & \\
\hline Rubiaceae & Uncaria cordata cordata (Lour.) Merr. & Liana & & Medicinal \\
\hline Rubiaceae & Ixora grandifolia Zoll. \& Moritzi & Shrub & & Medicinal \\
\hline Rubiaceae & Ixora umbellata Koord. \& Valeton & Shrub & & \\
\hline Rubiaceae & Lasianthus cyanocarpus Jack & Shrub & & Medicinal \\
\hline Rubiaceae & Lasianthus densifolius Miq. & Shrub & Endemic & Medicinal \\
\hline Rubiaceae & Prismatomeris glabra (Korth.) Valeton & Shrub & & \\
\hline Rubiaceae & Psychotria angulata Korth. & Shrub & Endemic & Medicinal \\
\hline Rubiaceae & Saprosma scortechinii King \& Gamble & Shrub & & Medicinal \\
\hline Rubiaceae & Ixora congesta Roxb. & Shrub & & \\
\hline Rubiaceae & Mycetia malayana (Wall. ex Ridl.) Craib & Shrub & & \\
\hline Rubiaceae & Psychotria griffithii Hook.f. & Shrub & & Medicinal \\
\hline Rubiaceae & Urophyllum blumeanum (Wight) Hook.f. & Small Tree & & \\
\hline
\end{tabular}




\begin{tabular}{|c|c|c|c|c|}
\hline Rubiaceae & Aidia densiflora (Wall.) Masam & Tree & & \\
\hline Rubiaceae & Canthium confertum Korth. & Tree & & \\
\hline Rubiaceae & Diplospora malaccensis Hook.f. & Tree & & \\
\hline Rubiaceae & Gardenia tubifera Wall. & Tree & & \\
\hline Rubiaceae & Nauclea officinalis (Pierre ex Pit.) Merr. \& Chun & Tree & & Medicinal \\
\hline Rubiaceae & Nauclea subdita (Korth.) Steud. & Tree & & \\
\hline Rubiaceae & Psydrax maingayi (Hook.f.) Bridson & Tree & & \\
\hline Rubiaceae & Timonius corneri $\mathrm{K} . \mathrm{M}$. Wong & Tree & & \\
\hline Rubiaceae & Urophyllum leucophloem Ridl. & Tree & Endemic & Medicinal \\
\hline Rutaceae & Maclurodendron porteri (Hook.f.) T.G. Hartley & Tree & Endemic & \\
\hline Rutaceae & Zanthoxylum myriacanthum Wall. & Tree & & Medicinal \\
\hline Sapindaceae & Lepisanthes tetraphylla (Vahl) Radlk. & Small tree & Endemic & Medicinal \\
\hline Sapindaceae & Lepisanthes senegalensis (Poir.) Leenh. & Tree & & Medicinal \\
\hline Sapindaceae & Xerospermum noronhianum (Blume) Blume & Tree & & \\
\hline Sapindaceae & Allophylus cobbe (L.) Raeusch. & Tree & & Medicinal \\
\hline Sapotaceae & Palaquium gutta (Hook.f.) Baill. & Tree & & \\
\hline Sapotaceae & Palaquium rostratum (Miq.) Burck & Tree & & \\
\hline Sapotaceae & Payena dasyphylla (Miq.) Pierre & Tree & & \\
\hline Sapotaceae & Payena lucida A. DC. & Tree & & \\
\hline Sapotaceae & Pouteria maingayi (C.B. Clarke) Baehni & Tree & & \\
\hline Sapotaceae & Pouteria malaccensis (C.B. Clarke) Baehni & Tree & & \\
\hline Schizaeaceae & Lygodium auriculatum (Willd.) Alston. & Fern & & \\
\hline Scrophulariaceae & Cyrtandromoea repens Ridl. & Herb & & Medicinal \\
\hline Selaginellaceae & Selaginella minutifolia Spring & Fern & & Medicinal \\
\hline Selaginellaceae & Selaginella intermedia (Blume) Spring & Fern & & Medicinal \\
\hline Simarubaceae & Brucea javanica (L.) Merr. & Shrub & & Medicinal \\
\hline Simarubaceae & Eurycoma longifolia Jack & Treetlet & & Medicinal \\
\hline Smilacaceae & Smilax calophylla Wall. ex A. DC & Shrub & Endemic & Medicinal \\
\hline Solanaceae & Lycianthes laevis (Dunal) Bitter & Shrub & & Medicinal \\
\hline Sterculiaceae & Sterculia cuspidata R.Br. & Small Tree & & \\
\hline Sterculiaceae & Pterospermum javanicum Jungh. & Tree & & Medicinal \\
\hline Thelypteridaceae & Pronephrium repandum (Fée) Holttum & Fern & & \\
\hline Thymelaeaceae & Aquilaria sp. & Tree & & Medicinal \\
\hline Thymelaeaceae & Gonystylus affinis Radlk. & Tree & & Medicinal \\
\hline Tiliaceae & Pentace macrophylla King & Tree & Endemic & \\
\hline Tiliaceae & Pentace strychnoidea King & Tree & & \\
\hline Tiliaceae & Schoutenia accrescens (Mast.) Curtis & Tree & & \\
\hline Ulmaceae & Gironniera parvifolia Planch & Tree & & \\
\hline Ulmaceae & Girroniera subaequalis Planch. & Tree & Endemic & \\
\hline Verbenaceae & Clerodendrum deflexum Wall. & Shrub & & Medicinal \\
\hline Verbenaceae & Clerodendrum laevifolium Blume & Shrub & & \\
\hline Verbenaceae & Teijsmanniodendron hollrungii (Warb.) Kosterm. & Small Tree & & \\
\hline Verbenaceae & Teijsmanniodendron coriaceum (C.B. Clarke) & Tree & & \\
\hline Verbenaceae & Vitex pinnata $\mathrm{L}$. & Tree & & Medicinal \\
\hline Violaceae & Rinorea anguifera (Lour.) Kuntze & Tree & & Medicinal \\
\hline Violaceae & Rinorea sclerocarpa (Burgersd.) M. Jacobs & Tree & & \\
\hline Vitaceae & Tetrastigma lawsoni (King) Burkill ex A.W. Hill & Liana & Endemic & \\
\hline Vittariaceae & Anthrophyum callifolium Blume & Epiphyte & & \\
\hline Woodsiaceae & Diplazium bantamense Blume & Fern & & Medicinal \\
\hline Zigiberaceae & Zingiber curtisii Holttum & Herb & Endemic & Medicinal \\
\hline Zingiberaceae & Etlingera metriocheilos (Griff.) R.M. Sm. & Herb & & Medicinal \\
\hline Zingiberaceae & Globba pendula Roxb. & Herb & Endemic & Medicinal \\
\hline Zingiberaceae & Globba variabilis Ridl. & Herb & & Medicinal \\
\hline Zingiberaceae & Alpinia scabra (Blume) Baker & Herb & & \\
\hline
\end{tabular}

